\title{
fSTRUCTURE, CONDUCT, AND PERFORMANCE OF NUCLEUS ESTATE AND SMALLHOLDER (NES) SCHEME IN OIL PALM SECTOR IN SOUTH KALIMANTAN
}

\author{
Hamdani, Nuri Dewi Yanti, Nina Budiwati \\ Department of Agricultural Socio-economics, Faculty of Agriculture \\ University of Lambung Mangkurat, Banjarbaru, South Kalimantan, Indonesia \\ Email : hdani342@gmail.com
}

\begin{abstract}
The purpose of this study was to analyze the structure, conduct, and performance of the nucleus estate and smallholder (NES) scheme in oil palm sector. The results showed that the conduct of partners in partnership generally was in accordance with the functions/tasks, rights and obligations regulated by the local government on the the nucleus estate and smallholder oil palm project. The market structure tended to be not competitive and the partnership system with the nucleus estate and smallholder (NES) scheme did not provide similar profits where the bargaining position of plasma farmers (smallholders) was relatively lower compared with that of the business partners (nucleus estates). Non-competitive market structure did not affect the transaction mechanism of Fresh Fruit Bunches (FFB) products from plasma plantations to necleus estates.
\end{abstract}

Keywords: conduct, oil palm, nucleus estate and smallholder, performance, structure

\section{INTRODUCTION}

The development of oil palm plantations in Indonesia has grown rapidly since 1970s, especially in 1980s. In Indonesia, there are three performers in oil palm plantations, namely State-Owed Plantation (PBN), Private-Owed Plantation (PBS) and Smallholder Plantation (PR). Data from the Directorate General of Plantation (2011) indicated that in 1980 the total area of oil palm plantations was 294,560 ha and in $20108,385,394$ ha, of which 52.07 percent was owned by Private-Owed Plantations, 40.39 percent by Smallholder Plantations, and 7.54 percent by State-owed Plantations (Appendix 4). In the period of $1980-2012$, the average growth of palm oil production per year was 10.13 percent; in 2006 the highest growth rate was 31.64 percent and in 2009 the lowest growth was -0.71 percent.

The implementation of partnership cooperation in the nucleus estate and smallholder (NES) scheme in oil palm sector still encounters many problems and obstacles, either before or after the conversion period. The period before the conversion is the critical time because the plants are generally immature and the plantation status is still under the nucleus estates's ownership. Basically, the obstacles facing plasma farmer households can be internal or external. The internal obstacles include (1) the low ability of farmers to develop their own products, (2) the low professionalism of farmers as plasma plantation managers, and (3) the lack of capital and low mastery of technology. The external obstacles are associated with (1) the business climate which is not good, (2) government policies which are not conducive and appropriate, (3) plantation facilities which are inadequate, especially transportation infrastructure, and (4) management coaching, training and extension which have not been optimal.

The purpose of this study was to analyze the structure, conduct, and performance of the the nucleus estate and smallholder (NES) scheme in oil palm sector.

\section{MATERIALS AND METHODS}

Data used in the study were secondary data, namely cross section and time series data. Cross section data were obtained from the survey by the research team of the Department of Agricultural Socio-Economics, Faculty of Agriculture, University of Lambung Mangkurat in 2016. Tanah Laut Regency was purposively selected based on the consideration that the regency had the most projects of nucleus estate and smallholder (NES) in oil palm to implement. Furthermore, two plantations, which implemented the nucleus estate and smallholder (NES) scheme in oil palm, were intentionally chosen. From each plantation, two sample villages were chosen (10 villages). From each village, 30 households of farmer models were then taken.

The analysis model was used to analyze the structure, conduct and 
performance and policy strategies in developing the nucleus estate and smallholder (NES) scheme in oil palm sector with the aid of SCP analysis.

Data analysis methods used in this study referred to the method used by Firdaus, et al. (2008). These methods were classified into three groups, namely analysis of industrial structure, industrial conduct, and industrial performance. However, due to a lack of data, only the relevant methods were used in the analysis.

\section{RESULTS AND DISCUSSION}

\section{Structure, Conduct and Performance of the Nucleus Estate and Smallholder (NES) scheme in Oil Palm Sector}

The structure, conduct, and performance of oil palm plantations in Indonesia cannot be separated from the linkage between upstream and downstream industrial plantations, so the analysis of the structure, conduct, and performance of oil palm plantations with the scheme of partnership system of nucleus estate and smallholder (NES) can use the criteria of backward linkages and forward linkages (Arifin, 2000). Performance of plantation industry depends on the ability of the performers to combine traditional activities in the upstream sector with the modern activities in the downstream sector. Usually the upstream sector is highly dependent on natural conditions whereas the downstream sector involves technology. The government should create a regulation which allows plantation industry performers to improve their plantation performance through various facilities like building various infrastructures and establishing conducive working environment (Daihani, 2000).

Becoming the participants in the nucleus estate and smallholder (NES) oil palm project basically becomes the participants of partnership between smallholders as the plasma farmers and large plantations as the nucleus. To become plasma participants, farmers must meet some requirements that have been determined by local governments based on the instructions of the Directorate General of Plantation, Jakarta. Institutional system in the nucleus estate and smallholder (NES) scheme has been agreed by both parties when signing the loan agreement on giving the management of plasma plantation (conversion) from the nucleus estates to smallholders. The institutional system in the form of rules on the rights and obligations that must be obeyed by each participant in the nucleus estate and smallholder (NES) scheme is regulated in the South Sumatra Regional Regulation No. 17 of 1998.

When partnership participants (plasma and nucleus) do not comply with the rules, they can be sued with the sanctions in accordance with Chapter XIV of Article 37 on the Criminal Provisions and Chapter XV of Article 38 on the Investigators Regulation. Furthermore, the structure and conduct of these partnership performers are based on duties, obligations and rights set out in the partnership agreement. This guide is a reference for project performers of the nucleus estate and smallholder (NES) to behave as the participants in the nucleus and smallholder oil palm project. This conduct affects the performance of the nucleus estate and smallholder (NES) project as a whole.

In accordance with the concept of economic institution and the structureconduct-performance (S-B-P concept), as well as local government regulations above, the assessment of economic performance of oil palm plantations with the nucleus and smallholder (NES) scheme was studied based on the conduct of individual performer in NES, especially the conduct of plasma farmer households at every stage of activities, such as (1) land preparation and oil palm production in plasma plantations, and (2) oil palm marketing.

\section{Land Preparation and Oil Palm Production in Plasma Plantations}

The activities in the preparation stage and construction of plasma plantations are carried out by the nucleus until the plants are 4 years old (from planting the seedlings to the production). The activities include (1) the clearing and preparation of plasma plantation land, (2) nursery, (3) planting the seedlings and the soil cover plants, and (4) plant maintenance.

According to Hayami (2001), the plantation development requires a big initial capital, especially for the construction of infrastructure and therefore should be done by a company with a large-scale enterprise. The activities of clearing the lands and building infrastructure in oil palm plantations generally use the fund sources from outside the company. The fund sources vary depending on the type of project performed by the nucleus estate and smallholder (NES). The nucleus estate and smallholder project with a special system (NES-Sus) is financed by state revenue budgetary and expenditure (APBN) and foreign aid (World Bank), the 
nucleus estate and smallholder project for transmigration (NES-Trans) by the state revenue budgetary and expenditure (APBN), while the nucleus estate and smallholder project for small business (NES-KUK) by the state revenue budgetary and expenditure (APBN) or local revenue budgetary and expenditure (APBD).

The value of loans charged to plasma farmer households reflects the cost of the initial investment for opening plasma plantations and other supporting facilities. The cost components expensed as credit values include the costs for opening the plasma plantations until the plants produce, the cost for clearing the lands and building the production road around the plasma plantations.

During the pre-conversion period (before the plants reach 4 years old or when they are not yet productive), the management of plasma plantations becomes the responsibility of the nucleus whereas the farmers just become the employees and they are paid per working day, and the cost of payment is calculated as one component of the farmers' debts. In order to earn the additional family income, the farmers generally cultivate their yards and fields for food crops.

After the plants are able to produce (approximately at the age of 4 years old), the project party of the nucleus estate and smallholder (NES) makes an assessment on the plantation condition to find out whether it is eligible to convert the management of the the plantations to plasma farmers (conversion). The conversion is done when the plantations are able to produce so that the farmers can earn income and are able to repay the loans in installments. The plasma plantations are declared to be eligible when the conditions of the plantations are good (in category A), which can be seen from the number of trees per plot (about 2 hectares) with a minimum number of 240 .

If the number of palm trees in plasma plantations is less than the standard number, the conversion of plasma plantations is delayed, and the improvement of the plantations should be carried out. The decreasing number of palm trees in plasma plantations generally due to pests (especially the wild pigs), disease and lack of maintenance on plants aged less than two years and no immediate replanting.

After the conversion stage (year 4 to year 6), it is followed by the stage of development and supervision of plants by the nucleus and procurement of inputs and sale of the crops with the help of cooperative services. At this stage, the maintenance of plasma plantations is fully under the responsibility of plasma farmers. To facilitate the payment of the loans, the farmers must become bank customers individually and become members of farmer groups/cooperatives.

At the stage of the post-conversion to the debt repayment (after the sixth year), the nucleus estates still conduct training either on production, harvest or post-harvest. At each scheduled harvest activity, the fresh fruit bunches (FFB) are collected and transported by trucks belonging to the nucleus or cooperative to oil palm mills owned by the nucleus. All transactions are represented by farmer organization boards (farmer groups or cooperatives), and the plasma farmers receive the earnings from the sale of oil palm fruit every month. The cooperatives also help providing extentions, setting up the working groups, and securing the FFB price.

The components of transaction costs which have the largest share are the transportation cost, distance from plasma plantations to oil palm mills, condition of roads in the plantations, and the condition of conveyance which is an important determinant of the transport cost. The means of transport used to transport fress fruit bunches from plasma plantations to the mills are trucks and pick-up cars. Harvesting and transporting are done according to schedule, usually started in the morning and completed in the afternoon.

The oil palm age is a determining factor for CPO which in turn will determine the selling price of fresh fruit bunches. The Minister of Forestry and Plantation (2000), determined the selling price of the farmers' fresh fruit bunches based on the age of the plant; the price of fresh fruit bunches from the plants with the ages ranging from 5 to 9 years is slightly varied and lower than that from the plants with ages ranging from 10 to 20 years.

Based on the financial/economic eligibility criteria, all plasma plantations still have an $\mathrm{R} / \mathrm{C}$ worth more than one and a positive $B / C$. The calculation costs on these criteria do not include the amount of loan installment paid by the plasma farmers, but only include the cost components that are directly related to the activities in plasma plantations in order to truly reflect the performance of farmer households. 


\section{Oil Palm Marketing}

The marketing of fresh fruit bunches is tied to an agreement or contract declaring that the farmers must sell the products they produce to their partners (the nucleus), and the nucleus has an obligation to purchase at least $75 \%$ of the fresh fruit bunches from plasma plantations. The analysis of the marketing is reviewed through four aspects, namely (1) the distribution system, (2) market structure, (3) market conduct, and (4) market performance.

\section{Market Structure}

The market structure is a characteristic of organizing the product market, which strategically effect the competition and the establishment of market prices. According to Martin (1994), there were four important elements that could be used as a reference for determining the market structure of a product, namely (1) the concentration level of the sellers or the buyers, (2) the product differentiation, and (3) the presence or absence of obstacles in a business.

The concentration level of the sellers/buyers reflects the market players' bargaining power either as the sellers or buyers. The higher the concentration level of market players the stronger its position as a determinant of the price of a product. In the market of fresh fruit bunch products with the nucleus estate and smallholder (NES) scheme, the sellers are the number of farmer households who face the nucleus estates as the buyers.

When it is viewed from the area of plasma plantations collectively (business scale), it is generally larger than the business scale of the nucleus plantations. The relatively wide plasma plantations are owned by many farmers, around 3,000 to 4,000 farmer households, and they are difficult to manage at the time of the transaction. The concentration of transactors is precisely available on the buyer (the nucleus plantation) because there is only one nucleus that has one or more oil palm mills in each location of plasma plantations.

Ownership of oil palm mill as a nucleus-specific assets and palm fruit characteristics of plasma plantations that must be processed become the determining factor of bargaining position of oil palm market participants. This condition will automatically make the nucleus as a single buyer and the price maker. Although there are other buyers (non-nucleus), the transaction with them is very rarely done (illegal), and therefore the nonnucleus buyers do not become the important competitors in the marketing of oil palm products in the nucleus estate and smalholder (NES) project.

Pricing mechanism of fresh fruit bunches on the location of plasma plantations for all systems of the nucleus estate and smallholder (NES) tends to be uncompetitive in which a single buyer (nucleus) deals with many sellers (farmers). The economic institutions (cooperatives or farmer groups) that should become the places for the plasma farmers (as the sellers) to negotiate with the nucleus (as the buyer) have not functioned optimally. The farmer institution only serves as an intermediary in the product marketing and has not been able to represent farmers in the transaction with the nucleus.

The thing that should get attention is that the price level of fresh fruit bunches determined on the price formula by the Ministry of Forestry and Plantation in 1998 should result in the competitive purchase price of fresh fruit bunches in order to avoid the sale of fresh fruit bunches out of the official channel (suitable with the contract). Farmers always look for information of higher selling prices of fresh fruit bunches because the price information can be accessed in the market quite well by farmers either by radio or cellular phone. Basically, the price guidelines set by the government simply set the average price as a "minimum price" to be paid by the nucleus when they buy fresh fruit bunches from the farmers.

Basically, the formula price set by the Ministry of Forestry and Plantation in 1998 and 2000 aimed to preserve the effectiveness of the partnership between the nucleus estates and plasma farmers because it can (1) reduce the impact of fluctuations in the price of palm oil from the world market and domestic for one month on the price level of fresh fruit bunches in the farmer level, (2) assess the quality of plasma plantations based on overlay so that the quality of fresh fruit bunches is more uniform and the unity of members of farmer groups is maintained, and (3) enable the farmers to have certainty about the fresh fruit bunches sale because according to the contract, the nucleus is required to buy fresh fruit bunches from farmers at a minimum of $75.00 \%$ of the oil palm mill capacity.

According to the results of the study by Mulyana (2003) in Laily (2007), the selling price set by the government has basically reduced "the exploitation of the plasma farmers by the nucleus". If the government 
does not regulate the selling price of fresh fruit bunches in plasma plantations, the purchase price of fresh fruit bunches from the farmers is only $71.67 \%$ of the price set by the government. Based on the equation estimation of production conduct, a selling price factor is essential to the increasing productivity of plasma plantations because the effect of price changes in fresh fruit bunches on the productivity is very significant even though the productivity of fresh fruit bunches toward the price of fresh fruit bunches is unresponsive (inelastic). The increase in fresh fruit bunch price is expected to motivate farmers to manage their plantations in better ways. The results of the simulation also show that the impact of rising price of fresh fruit bunches with a smaller percentage $(15.00 \%)$ compared to the rising input price of variable with a greater percentage $(20: 00 \%)$ still gives a positive impact on the performance of farmer households, especially on the productivity of plasma plantations, oil palm revenue and income, and acceleration of credit payment period.

\section{Product Differentiation}

One way to distinguish the product price is by changing the product differentiation, either through processing or other marketing functions. In general, the oil palm fruits, such as fresh fruit bunches, sold by the farmers have relatively homogeneous characteristics so the farmers are not able to determine the different selling prices. Product differentiation can only be done when the fresh fruit bunches are processed to obtain value added, i.e. into palm oil or other processed products, but the investment costs of oil palm mill construction are very expensive so the farmers cannot do it individually or collectively.

In addition, some characteristics of fresh fruit bunches and the partnership agreement in the nucleus estate and smallholder (NES) scheme tend to inflict a financial loss to farmers, such as (1) the product cannot be consumed directly or sold to final customers, (2) the product is easily damaged and must be processed within 12 hours, (3) the product is bulky and requires a special transport means, and (4) the product should be sold to the oil palm mill owned by the nucleus. These characteristics of fresh fruit bunches and the partnership agreement in the nucleus estate and smallholder (NES) scheme have resulted in the farmer incapability to store the product to obtain time utility, to process their own products to gain form utility, and to sell the products to another location to get place utility. These characteristics make the farmers' bargaining position weaker in each transaction, so the position of plasma farmers tends just to become the price takers.

\section{Obstacles in business}

Some sources of obstacles in business are the existence of positive profits as the result of product differentiation, and the difference in the level of superiority of one manufacturer to another as the result of differences in business scale. Each plasma farmer has the same position in terms of rights and obligations as the participant of the nucleus estate and smallholder (NES), the relatively equal business scale (two hectares) and the same marketing manner and channels for the product marketing, so the competition among plasma farmers based on business scale does not happen.

Although it requires special conditions in order to become a participant in the nucleus estate and smallholder (NES) scheme, the small-scale business does not become an obstacle for smallholders to join the partnership system available in the research site. The government policy that opens the opportunity for smallholder plantations to join the partnership system by giving the easy access to the oil palm industry will generate business profit that is relatively small or close to zero, resulting in the free entry and exit into industry.

Based on the above details, the structure of the oil palm market tends to be uncompetitive, where a lot of sellers (plasma farmers) face a buyer (the nucleus), and the bargaining position is not balanced or in other words the nucleus is relatively stronger than the plasma farmers so the nucleus tends to affect the price of the products (price maker) and plasma farmers tend to become the price takers. In addition, the government intervention in determining the selling price and providing the information of the selling price which is not symmetrical has strengthened the uncompetitive market structure.

\section{Market Conduct}

Market conduct is a variety of activities or methods adopted by the market makers in the adjustment of its activities to market conditions. Plasma farmers, as the product sellers, have cooperation among farmers in farmer groups, and some farmer groups join the cooperatives, such as oil palm producer cooperatives (KPKS) or village unit 
cooperatives (KUD). Furthermore, the conduct of farmers in selling products whether through official or unofficial channels is usually based on economic and noneconomic considerations.

The sale of fresh fruit bunches from plasma plantations to the nucleus after the loan payment aims to prepare the plantation rejuvenation process for some of the funds deducted from the value of fresh fruit bunch sales after the credit payment is used for insurance funds of plantation rejuvenation (in the form of Idapertabun insurance). When all of the agreement is met by the partnership performers (plasma farmers and nucleus estates), the partnership system will run better and the continuity of cooperation within the nucleus estate and smallholder (NES) scheme will be maintained.

The conduct of cooperative as a forum for farmers helps schedule the harvest, transport, and record the number of fresh fruit bunches from the farmers sold to the nucleus, and then distribute the earnings of fresh fruit bunches to farmers based on the number of products registered through farmer groups at the beginning of each month. To compensate these services, the cooperative board obtains the commission in the form of the cost for transport when vehicles for the transport are owned by cooperatives, and the commission for the management fee that is paid by each plasma farmer based on the unit of products.

\section{Market Performance}

Dimensions that are often used in assessing the market performance are the level of efficiency, relationship of selling price and the producer cost, and promotional costs (Bain, 1959 in Martin, 1994), efficiency, profit, quality and market prices (Carlton and Perloff, 1994).

The level of business efficiency is strongly influenced by the business scale; the greater the business scale (to some extent), the more efficient it will be. In general, the market performance of oil palm in the location of plasma plantations in the nucleus estate and smallholder (NES) scheme is still profitable for farmers or still efficient because the profit per unit of product is still positive.

The third alternative model proposed by Tambunan (1996) is that the farmers' economic institutions should deal with large estates (the nucleus) through the way where farmer households join the cooperative institution as a single seller facing the nucleus as a single buyer. If this can be realized, the market structure is going to approach a bilateral monopoly. This can be done when the farmer institutions (farmer groups, oil palm producer cooperatives (KPKS) or village unit cooperatives (KUD) is empowered in terms of management, technology, and capital. If the model of bilateral monopoly can be realized, the price of the product is the result of the negotiation between both parties for a transaction with relatively equal bargaining power.

The role of the government for the realization of the market structure is indispensable, with the improvement of pricing system, such as (1) the pricing should be determined more frequently e.g. every week if it is possible every day instead of once in a month, (2) the pricing should be more transparent, especially in determining yield $(R)$ and $K$ factor with the involvement of farmer institutions, (3) the determination of $R$ should be based on the smaller plantation area to make it more representative, and (4) the waiting period of payments for fresh fruit bunches to farmers should be shortened and when possible in cash so that the farmers are not "trapped" with debts by traders due to lack of cash.

\section{CONCLUSIONS AND SUGGESTION}

\section{Conclusions}

The conduct of partnership performers generally has been in accordance with the functions/tasks, rights and obligations regulated by the local government on the nucleus estate and smallholder (NES) oil palm project.

The market structure tends to be not competitive and the partnership system with the nucleus estate and smallholder (NES) scheme has not provided equal profits where the bargaining position of farmers is relatively lower than its partner (the nucleus) and the role of farmer economic organizations (cooperatives) has not been as expected. The market structure which is not competitive affects the transaction mechanism of the fresh fruit bunches from plasma plantations to the nucleus estate.

Based on some technical criteria (conversion age, productivity, and loan payment period) and financial/economic criteria, the performance of plasma plantations is quite good.

\section{Suggestion}

The market structure which is not competitive affects the transaction mechanism of fresh fruit bunches from plasma plantations to the nucleus estates. 
The transaction of products which is based on the fresh fruit bunches pricing still has some weaknesses, which makes the farmers tend just to become the price takers. If the farmer organizations (cooperatives and farmer groups) are more empowered to improve their bargaining power, the level of selling prices of fresh fruit bunches is expected to be higher and more profitable for the farmer households. Overall, the market performance is still efficient, reflected by the positive profit level of plasma farmers.

\section{REFERENCES}

Department of Agriculture (2007). Prospect and Agribusiness Development Direction of Oil Palm. Edition 2. Research and Development Agency. Jakarta.

Directorate General of Plantation (2011). Indonesia's Plantation Statistics Oil Palm 2010 - 2012. Ministry of Agriculture. Jakarta.

Directorate General of Plantation (2012). Production Increase Policy, Productivity, and Oil Palm Quality. Presented at: Indonesia Palm Oil, Mechinery and Technology Exhibition \& Conference (2012) April 26 to 27. Riau.

Susanto R.D. (2011). Analysis of Supply and Demand of Indonesian Palm Oil: Impact on the Indonesian Edible Oil Industry. Thesis. University of Indonesia. Jakarta.

Sukiyono, K. (1995). NES and Response of Offering Palm Oil Producers. Journal of Oil Palm in Indonesian. Oil Palm Journal Research 3 (2): 163-190.

Saputro, T., Herman, U. Fajar, B. and Dradjat, B.W. (1995). Assessment of Plantation Agribusiness Development. Book I: Institutional System Assessment of PostConversion of the nucleus estate and smallholder (NES) Plantation. Research and Development Agency, Ministry of Agriculture. Jakarta.

Herman and Dradjat, B.W. (1996). Effectiveness of Village Unit Cooperative (KUD) in activities in the nucleus estate and smallholder (NES) of Oil Palm. Plantations Agribusiness Assessment Journal, (1): 8-16.
Zulher (1993). Impact of Development of Smallholders (the nucleus estate and smallholder (NES)-Special PTP V, Sei Tapung) to the Regional Development in Tandun District, Kampar Regency in Riau province. Master of Science Thesis. Postgraduate Program, Bogor Agricultural University. Bogor.

Marnis (1993). Impact of the nucleus estate and smallholder (NES)-Bun of Oil Palm to its Farmer Income in Kampar Regency, Riau. Master of Science Thesis. Postgraduate Program, Bogor Agricultural University. Bogor.

Daswir and Lubis, A.U. (1995). Economic Analysis of Oil Palm Plantation Business with Primary Cooperatives Credit for Members. Journal of Oil Palm Research, 3 (2): 151-162.

Salman, M and Wahyono, T. (1998). Level of Income and Sustainable of Plasma Farmers of the nucleus estate and smallholder (NES) of oil palm. Journal. Journal of Oil Palm Research Center. Indonesian Plantation Research Association, Medan, 6 (3): 127-132. 